JURNAL RISET MAHASISWA AKUNTANSI (JRMA)

Volume 8, No. 1, Tahun 2020

e-ISSN : 2715 - 7016

\title{
PENGARUH PENERAPAN STANDAR AKUNTANSI PEMERINTAH, PEMANFAATAN SISTEM INFORMASI AKUNTANSI DAN PENGAWASAN KEUANGAN TERHADAP KUALITAS LAPORAN KEUANGAN PEMERINTAH DAERAH (Studi Empiris pada OPD Kota Malang)
}

\author{
Nanda Saputri Yanti \\ Email:nandasyaputri98@gmail.com \\ Anwar Made \\ Supami Wahyu S \\ Program Studi Akuntansi, Fakultas Ekonomika dan Bisnis, Universitas Kanjuruhan, Malang
}

\begin{abstract}
ABSTRAK
Penelitian ini bertujuan untuk mengetahui pengaruh secara parsial dan simultan pengaruh penerapan standar akuntansi pemerintah, pemanfaatan sistem informasi akuntansi dan pengawasan keuangan terhadap kualitas laporan keuangan pemerintah daerah. Populasi dalam penelitian ini adalah pejabat struktural dan staf bagian fungsi keuangan pada Organisasi Perangkat Daerah (OPD) Kota Malang. berjumlah 14 instansi dengan responden sebanyak 71. Pengambilan sampel menggunakan teknik purposive sampling. Dengan metode pengumpulan data menggunakan kuesioner. Analisis data menggunakan analisis regreasi linier berganda dengan menggunakan program SPSS versi 22. Hasil penelitian menunjukan bahwa penerapan standar akuntansi pemerintah berpengaruh signifikan terhadap kualitas laporan keuangan pemerintah daerah, pemanfaatan sistem informasi akuntansi tidak berpengaruh terhadap kualitas laporan keuangan pemerintah daerah, dan pengawasan keuangan berpengaruh signifikan terhadap kualitas laporan keuangan pemerintah daerah. Dan secara simultan penerapan standar akuntansi pemerintah, pemanfaatan sistem informasi akuntansi, dan pengawasan keuangan berpengaruh signifikan terhadap kualitas laporan keuangan pemerintah daerah.
\end{abstract}

Kata Kunci : SAP, SIA, Pengawasan Keuangan, Kualitas Laporan Keuangan

\section{ABSTRACT}

Research it aims for the knowing influence in a manner. partially and simultaneous influence application the standard accounting government, utilization the system information accounting and supervision finance towards report quality finance the government area. Population in this research is. officials structural and section staff financial function in the organization Device Regional (OPD) City Poor. totaled 14 agency with respondent 71 . Retrieval the sample to use purposive technique sampling. With method data collection using a questionnaire. Analysis the data use analysis linear regreasi multiple with using SPSS version 22. Results research shows that application accounting standard the government influential significant to the quality local government financial reports, utilization the system information accounting has no effect towards report quality government finance area, and supervision financial influence significantly on the quality of local government financial reports. And simultaneous application government accounting standards, utilization of information systems accounting, and financial supervision significant effect towards quality financial statements the government area. 
Nanda Saputri Yanti, Pengaruh Penerapan Standar Akuntansi Pemerintah, Pemanfaatan Sistem Informasi Akuntansi Dan Pengawasan Keuangan Terhadap Kualitas Laporan Keuangan Pemerintah

Daerah

Keywords : Government Accounting Standards, Accounting Information Systems, Financial Oversight, Quality of Financial Statements

\section{PENDAHULUAN}

Seiring Perkembangan Akuntansi Sektor Publik di Indonesia, kebutuhan akan akuntabilitas sebagai wujud pertanggungjawaban pemerintah kepada masyarakat atas kinerja pemerintah menjadi tuntutan masyarakat terhadap penyelenggaraan pemerintah yang baik. sehingga mendorong pemerintah pusat dan daerah untuk menerapkan akuntabilitas publik. Sesuai Undang-undang No. 17 Tahun 2003 Tentang Keuangan Negara dalam mewujudkan good governance, pemerintah dituntut untuk melaksanakan pengelolaan keuangan secara transparan dan akuntabel. Undang-undang Nomor 23 Tahun 2014 Tentang Pemerintah Daerah yang berupa Laporan Keuangan, sebagai wujud pertanggungjawaban pemerintah daerah atas pengelolaan keuangan daerah selama satu tahun anggaran dalam pelaksanaan otonomi daerah dan penyelenggaraan operasional pemerintah. dengan mengeluarkan PP No. 71 Tahun 2010 Tentang Standar Akuntansi Pemerintah yang sudah memuat berbagai persyaratan dalam menyajikan informasi laporan keuangan yang berkualitas diantaranya relevan, andal, dapat dibandingkan dan dapat dipahami (Nurlaila, 2014) SAP merupakan aspek penting yang ditetapkan dalam menyusun dan menyajikan laporan keuangan pemerintah daerah, tujuan diberlakukan Standar Akuntansi Pemerintah agar laporan keuangan yang dihasilkan dapat meningkatkan kualitas laporan keuangan pemerintah pusat maupun daerah.

Pemanfaatan Sistem Informasi Akuntansi juga dapat meningkatkan kualitas LKPD Diana (2014). Untuk mendapatkan informasi yang berkualitas perlu adanya sebuah sistem yang mengelola data menjadi sebuah informasi yang berharga yang dituntut menghasilkan informasi yang cepat, tepat dan akurat. Pengawasan Keuangan ini sangat berperan penting dalam meningkatkan kualitas laporan keuangan pemerintah, Pengawasan Keuangan diperlukan agar proses dalam pengelolaan anggaran daerah berjalan dengan baik, sesuai dengan kepatuhan terhadap peraturan perundang-undangan, sehingga dapat menghasilkan kinerja keuangan yang baik. Ikhwanul Haza (2015).

Fenomena yang terjadi di pemerintah Kota Malang yaitu pada laporan keuangan tahun 2018 masih ditemukan adanya kelemahan pengendalian dan ketidakpatuhan terhadap peraturan perundang-undangan namun permasalahan itu tidak mempengaruhi kewajaran atas penyajian LKPD. "Harapan BPK atas laporan keuangan pemerintah daerah yang telah diperiksa oleh badan pengawasan keuangan dapat dijadikan dasar pengambilan keputusan terutama terkait dengan penganggaran ujarnya. (malangkota, 27 Mei 2019). BPK Jatim menyerahkan laporan hasil pemeriksaan (LHP) atas lapoan daerah (LKPD) tahun anggaran 2018. Sembilan pemerintah berhasil mempertahankan Opini Wajar Tanpa Pengecualian (WTP). Namun dalam pemeriksaan atas LKPD 2018 pada Sembilan pemerintah daerah ditemukan permasalahan diantaranya (1) Terdapat pembayaran jeda konsultasi perencanaan yang melebihi standar yang ditetapkan kepala daerah, serta kekurangan volume dan kualitas atas pelaksanaan (2) Pemerintah Kabupaten/Kota belum melakukan verifikasi dan validasi (NOP) dan wajib pajak PBB perdesaan dan perkotaan (3) Pengelolaan asset tetap masih kurang memadai (4) Terdapat pembayaran intensif pajak daerah tidak sesuai ketentuan, (5) Pelaksanaan hibah baik uang maupun barang kurang memadai, (6) Aplikasi yang digunakan untuk menyusun laporan keuangan belum sepenuhnya bisa diandalkan. Serta, Aset Pemkot Malang kategori bidang tanah antre menunggu giliran untuk disertifikasi. BPKAD Kota Malang masih terus melakukan inventarisasi aset pemerintahan termasuk aset tanah, masih banyak aset belum tersertifikasi diklaim akibat batasan jumlah bidang tanah yang harus diajukan ke Badan Pertanahan Nasional. (MalangVoice, Aziz Ramadani- 18 Juni 2019). 
Nanda Saputri Yanti, Pengaruh Penerapan Standar Akuntansi Pemerintah, Pemanfaatan Sistem Informasi Akuntansi Dan Pengawasan Keuangan Terhadap Kualitas Laporan Keuangan Pemerintah

Daerah

\section{KAJIAN PUSTAKA}

Standar Akuntansi Pemerintah (SAP)

Standar Akuntansi Pemerintah merupakan pedoman dan prinsip-prinsip akuntansi dalam menyusun dan menyajikan laporan keuangan. Diterapkan dilingkungan pemerintah pusat dan dapertemennya maupun daerah dan dinas-dinasnya. SAP berguna bagi penyusunan laporan keuangan dalam menentukan informasi yang harus disajikan kepada pihak diluar instansi.

\section{Sistem Informasi Akuntansi}

Menurut Hanaffi, (2017). SIA merupakan Sistem Informasi yang mampu menangani dan mempercepat proses pengelolaan keuangan daerah, mulai dari penyususnan anggaran, sampai dengan pelaporan keuangan daerah. Sedangkan menurut Halim (2010:8) SAK atau disebut juga dengan sistem informasi akuntansi keuangan, diperlukan untuk menghasilkan informasi kepada pihak luar sesuai dengan standar.

\section{Pengawasan Keuangan}

Peraturan Menteri Dalam Negeri Nomor 51 Tahun 2010, Pengawasan atas Penyelenggaraan Pemerintah Daerah adalah proses kegiatan yang ditunjukan untuk menjamin agar pemerintahan daerah berjalan secara efektif dan efisien sesuai dengan rencana dan ketentuan peraturan perundang-undangan. Pengawasan diperlukan untuk menghindari adanya kemungkinan penyelewengan atau penyimpangan dari rencana yang telah ditetapkan. Sebagai parameter penilaian keberhasilan dan kegagalan pelaksanaan kinerja Menurut Peraturan Menteri Dalam Negeri No. 8 Tahun 2009 Perubahan atas Permendagri No. 23 Tahun 2007 Tentang Tata Cara Pengawasan Atas Penyelenggaraan Pemerintah Daerah, yang termasuk dalam ruang lingkup pengawasan pengelolaan keuangan daerah ialah Pelaksanaan dan penatausahaan keuangan daerah, Pertanggungjawaban dan Pendapatan dan belanja daerah

\section{Kualitas Laporan Keuangan}

Menurut Sofyan Syafri Harahap (2013:146) Kualitas laporan keuangan merupakan kriteria persyaratan yang dianggap dapat memenuhi keinginan para pemakai atau pembaca laporan keuangan. Sedangkan Menurut Yadiati (2017:32) merupakan kegiatan melaporkan informasi keuangan guna memenuhi kebutuhan pengguna sekaligus memberikan perlindungan kepada pemilik dengan mendasarkan pada karakteristik kualitatif informasi keuangan dan pengungkapan secara penuh dan wajar.

\section{Kerangka Konseptual}

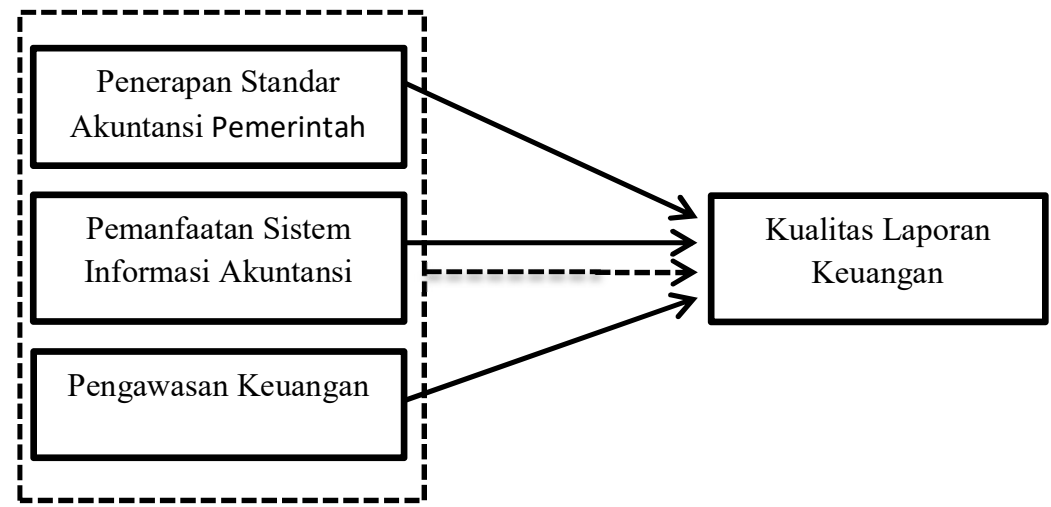

Gambar 2.1

Keterangan: Uji Simultan 
Nanda Saputri Yanti, Pengaruh Penerapan Standar Akuntansi Pemerintah, Pemanfaatan Sistem Informasi Akuntansi Dan Pengawasan Keuangan Terhadap Kualitas Laporan Keuangan Pemerintah

Daerah

\section{UJi Parsial}

H1: Penerapan Standar Akuntansi Pemerintah, Pemanfaatan Sistem Informasi Akuntansi dan Pengawasan Keuangan berpengaruh terhadap Kualitas Laporan Keuangan Pemerintah Daerah.

H2: Standar Akuntansi Pemerintah berpengaruh positif terhadap Kualitas Laporan Keuangan Pemerintah Daerah

H3: Pemanfaatan Sistem Informasi Akuntansi Berpengaruh positif terhadap Kualitas Laporan Keuangan Pemerintah Daerah

H4: Pengaruh Pengawasan Keuangan Pemerintah Daerah berpengaruh positif terhadap Kualitas Laporan Keuangan Pemerintah Daerah

\section{METODE PENELITIAN}

Penelitian ini juga menggunakan metode analisis berupa regresi linier berganda. Populasi dan sampel yang peneliti gunakan yakni pada Organisasi Perangkat Daerah Kota Malang dengan sampel 14 OPD dengan responden 71 orang, teknik yang digunakan yakni menggunakan purposive sampling. Hasil penelitian ini menunjukan variabel Standar Akuntansi Pemerintah, Sistem Informasi Akuntansi dan Pengawasan Keuangan berpengaruh positif dan signifikan terhadap Kualitas Laporan Keuangan Pemerintah Daerah (LKPD).

\section{HASIL DAN PEMBAHASAN}

Dalam penelitian ini karakteristik responden yang dapat di golongkan berdasarkan jenis kelamin, usia, dan tingkat pendidikan. Berdasarkan karakteristik tersebut maka dapat di simpulkan bahwa jenis kelamin dominan laki-laki berjumlah 60 orang atau 84\%, perempuan 11 orang atau 16\%. Kemudian rata-rata usia di Organisasi Perangkat Daerah Kota Malang dapat kita lihat usia 20-30 sebanyak 20 orang atau $28 \%$, usia $31-40$ sebanyak 21 orang atau $30 \%$, usia 41-50 sebanyak 16 orang atau $23 \%$ kemudian usia diatas 50 tahun sebanyak 14 orang atau $19 \%$. Kemudian di lihat dari tingkat pendidikan yang ada di Organisasi Perangkat Daerah Kota Malang dari tingkat Diploma sebanyak 20 orang atau $28 \%$, dan tingkat pendidikan S1 sebanyak 51 orang atau $72 \%$. Dari hasil uji validitas dari semua item dan pernyataan dikatakan Valid sehingga semua item dapat digunakan untuk dianalisis lebih lanjut, hal ini dapat di tunjukan dengan nilai korelasi $\mathrm{r}$ hitung lebih besar dari $\mathrm{r}$ tabel sebesar 0,230. Kemudian dilihat dari hasil uji reabilitas penelitian ini dikatakan reliable karena memiliki nilai alfa cronbac lebih dari 0,6 .

\section{Uji Asumsi Klasik}

Berdasarkan hasil uji normalitas dapat kita ketahui bahwa data yang di peroleh memiliki nilai signifikan 0,200 hal ini menunjukan bahwa data dapat dikatakan normal dan model data tersebut layak digunakan, Hasil uji multikolinieritas masing-masing variabel memiliki nilai VIF $<10$ maka model regresi tidak terdapat gejala multikolinieritas. dan hasil uji heterokedasitas masing-masing variabel menunjukan nilai $p$-value $>0,05$ sehingga disimpulkan bahwa semua variabel bebas dari masalah heteroskedastisitas. 
Nanda Saputri Yanti, Pengaruh Penerapan Standar Akuntansi Pemerintah, Pemanfaatan Sistem Informasi Akuntansi Dan Pengawasan Keuangan Terhadap Kualitas Laporan Keuangan Pemerintah

\section{Regresi Linier Berganda}

\begin{tabular}{|c|c|c|c|c|c|}
\hline \multirow[t]{2}{*}{ Variabel Independen } & \multicolumn{2}{|c|}{$\begin{array}{l}\text { Unstandardized } \\
\text { Coefficients }\end{array}$} & \multirow[t]{2}{*}{ Beta } & \multirow[t]{2}{*}{ t-hitung } & \multirow[t]{2}{*}{ Sign. $\mathrm{t}$} \\
\hline & $\mathrm{B}$ & Std.Error & & & \\
\hline (Constant) & 5,928 & 3,830 & & 1,548 & 0,126 \\
\hline $\begin{array}{lr}\text { Penerapan } & \text { Standar } \\
\text { Akuntansi Pemerintah }\left(\mathrm{X}_{1}\right)\end{array}$ & 0,237 & 0,083 & 0,313 & 2,855 & 0,006 \\
\hline $\begin{array}{l}\text { Pemanfaatan } \quad \text { Sistem } \\
\text { Informasi Akuntansi }\left(\mathrm{X}_{2}\right)\end{array}$ & 0,293 & 0,159 & 0,190 & 1,835 & 0,071 \\
\hline $\begin{array}{l}\text { Pengawasan Keuangan } \\
\left(\mathrm{X}_{3}\right)\end{array}$ & 0,354 & 0,114 & 0,338 & 3,114 & 0,003 \\
\hline R Square $\left(\mathrm{R}^{2}\right)$ & 0,473 & & & & \\
\hline Adjusted R Square & 0,449 & & & & \\
\hline F- hitung & 20,033 & & & & \\
\hline Sign-F & 0,000 & & & & \\
\hline
\end{tabular}

Sumber: Data diolah peneliti, 2020

Dari tabel diatas menunjukan persamaan regresi sebagai berikut :

$\mathrm{Y}=5,928+0,237 \mathrm{X} 1+0,293 \mathrm{X} 2+0,354 \mathrm{X} 3+\mathrm{e}$

Dari persamaan regresi tersebut, diketahui bahwa :

Nilai konstanta sebesar 5,928 memiliki arti bahwa jika tidak ada variabel SAP $\left(\mathrm{X}_{1}\right)$, Sistem Informasi Akuntansi $\left(\mathrm{X}_{2}\right)$, dan Pengawasan Keuangan $\left(\mathrm{X}_{3}\right)$, maka Kualitas LKPD ( $\left.\mathrm{Y}\right)$ sebesar 5,928 atau sangat tinggi.

Koefisien regresi Penerapan Standar Akuntansi Pemerintah $\left(X_{1}\right)$ sebesar 0,237 yang artinya jika variabel Penerapan SAP $\left(\mathrm{X}_{1}\right)$ ditingkatkan kenaikannya satu kali, maka variabel ( $\mathrm{Y}$ ) akan mengalami suatu peningkatan sebesar 0,237 dengan asumsi variabel lain bernilai tetap atau tidak berubah.

Koefisien regresi Pemanfaatan Sistem Informasi Akuntansi $\left(X_{2}\right)$ sebesar 0,293 yang artinya jika variabel Pemanfaatan SIA $\left(\mathrm{X}_{2}\right)$ ditingkatkan kenaikannya satu kali, maka variabel Kualitas LKPD (Y) mengalami peningkatan sebanyak 0,293 dengan variabel lain bernilai tetap atau tidak berubah.

Koefisien regresi Pengawasan Keuangan $\left(\mathrm{X}_{3}\right)$ sebesar 0,354 yang artinya jika variabel Pengawasan Keuangan $\left(\mathrm{X}_{3}\right)$ ditingkatkan kenaikannya satu kali, maka variabel Kualitas Laporan Keuangan Pemerintah Daerah (Y) akan mengalami peningkatan sebesar 0,354 dengan asumsi variabel lain bernilai tetap atau tidak berubah.

\section{Uji Hipotesis}

Uji F

Uji F dilakukan untuk mengetahui pengaruh dari kesemua variabel bebas terhadap variabel terikat dengan cara simultan. Dalam menentukan suatu hipotesis diterima atau ditolak adalah dengan membandingkan $\mathrm{F}$ hitung dengan $\mathrm{F}$ tabel, atau dapat juga melihat dari nilai signifikansi yang ada dengan penetapan batas kesalahan sebesar 0,05. Berikut adalah ketentuan hipotesis diterima atau ditolak 
Nanda Saputri Yanti, Pengaruh Penerapan Standar Akuntansi Pemerintah, Pemanfaatan Sistem Informasi Akuntansi Dan Pengawasan Keuangan Terhadap Kualitas Laporan Keuangan Pemerintah

Daerah

Uji hipotesis 1 Penerapan SAP, Pemanfaatan SIA dan Pengawasan Keuangan secara simultan berpengaruh terhadap Kualitas Laporan Keuangan Pemerintah Daerah. Hasil uji regresi menunjukkan bahwa Fhitung sebesar 20,033 dengan signifikasi sebesar 0,000. Maka disimpulkan bahwa variabel Independen secara bersama-sama atau simultan berpengaruh signifikan terhadap variabel Dependen. Dengan demikian dapat disimpulkan bahwa hipotesis 1 dapat diterima.

Uji $t$

Uji $t$ dilakukan untuk memahami pengaruh secara parsial pada masingmasing variabel bebas terhadap variabel terikat. Untuk menentukan suatu hipotesis dapat diterima atau ditolak dapat melalui perbandingan antara $t$ hitung dengan $t$ tabel, atau dapat juga melihat dari nilai signifikansi yang ada dengan penetatapan batas kesalahan sebesar 0,05. Berikut adalah ketentuan hipotesis diterima atau ditolak. Berdasarkan hasil analisis yang telah peneliti teliti maka dapat kita lihat penjelasan di bawah ini

Uji hipotesis 2 Hasil uji regresi variabel Penerapan SAP $\left(\mathrm{X}_{1}\right)$ menunjukan bahwa nilai signifikan $t$ sebesar $0,006<0,05$ berarti ada pengaruh yang positif dan signifikan terhadap variabel Kualitas Laporan Keuangan Pemerintah Daerah (Y) Dengan demikian dapat disimpulkan bahwa hipotesis 2 dapat diterima.

Uji hipotesis 3 Hasil uji regresi variabel Pemanfaatan SIA $\left(\mathrm{X}_{2}\right)$ menunjukkan bahwa nilai signifikan $\mathrm{t}$ sebesar $0,071>0,05$, berarti tidak ada pengaruh yang signifikan terhadap variabel Kualitas Laporan Keuangan Pemerintah Daerah (Y). Dengan demikian dapat disimpulkan bahwa hipotesis 3 ditolak.

Uji hipotesis 4 Hasil uji regresi variabel Pengawasan Keuangan $\left(\mathrm{X}_{3}\right)$ menunjukkan bahwa nilai signifikan $\mathrm{t}$ sebesar 0,003 $<0,05$ berarti ada pengaruh yang positif dan signifikan terhadap variabel Kualitas Laporan Keuangan Pemerintah Daerah (Y). Dengan demikian dapat disimpulkan bahwa hipotesis 4 dapat diterima.

Koefisien Determinasi

Pengujian koefisien determinasi $\left(\mathrm{R}^{2}\right)$ digunakan untuk mengukur seberapa besar presentase pengaruh variabel independen $(X)$ terhadap variabel dependen $(Y)$. Nilai koefisien determinasi adalah antara nol atau satu, nilai $\left(\mathrm{R}^{2}\right)$ yang kecil berarti kemampuan variabel-variabel independen dalam menjelaskan variasi variabel dependen. Hasil analisi diatas menjelaskan bahwa nilai pada koefisien determinasi ( $\mathrm{R}$ Square) sebesar 0,473 atau jika diubah dalam bentuk presentase menjadi sebesar 47,3\%. Hasil ini dapat menjelaskan bahwa Penerapan Standar Akuntansi Pemerintah, Pemanfaatan Sistem Informasi Akuntansi dan Pengawasan Keuangan mampu memberikan kontribusi sebesar 47,3\% terhadap Kualitas Laporan Keuangan Pemerintah Daerah. Sisanya sebesar 52,7\% ditentukan oleh variabel lain yang tidak diteliti.

\section{PEMBAHASAN}

Pengaruh Penerapan Standar Akuntansi Pemerintah, Pemanfaatan Sistem Informasi Akuntansi dan Pengawasan Keuangan terhadap Kualitas Laporan Keuangan Pemerintah Daerah

Hail dari pengujian hipotesis dalam penelitian ini bahwa variabel Penerapan SAP, Pemanfaatan SIA dan Pengawasan Keuangan secara simultan berpengaruh terhadap Kualitas Laporan Keuangan Pemerintah Daerah. Karena Standar Akuntansi Pemerintah merupakan pedoman atau acuan dalam penyusunan laporan keuangan pemerintah daerah disusun mengacu pada kerangka konseptual SAP. Dengan diterapkannya Standar Akuntansi Pemerintah pencatatan laporan keuangan akan menjadi akurat dan informasi yang dihasilkan pemerintah pusat dan daerah lebih berkualitas. Faktor yang mempengaruhi Kualitas 
Nanda Saputri Yanti, Pengaruh Penerapan Standar Akuntansi Pemerintah, Pemanfaatan Sistem Informasi Akuntansi Dan Pengawasan Keuangan Terhadap Kualitas Laporan Keuangan Pemerintah

Daerah

Laporan Keuangan Pemerintah Daerah yaitu Sistem Informasi Akuntansi yang mengelola data menjadi sebuah informasi berharga yang tepat dan akurat. Selain itu Pengawasan Keuangan merupakan faktor yang dapat mempengaruhi kualitas laporan keuangan mencakup segala tindakan untuk menjamin agar pengelolaan keuangan negara dan daerah berjalan sesuai dengan rencana, ketentuan, dan undang-undang yang berlaku. Dengan adanya pengawasan yang baik maka alokasi anggaran publik yang tercermin dalam anggaran, pendapatan daerah dapat diperuntukan untuk kepentingan publik.

Pengaruh Penerapan Standar Akuntansi Pemerintah Daerah

Berdasarkan hasil Analisis bab sebelumnya telah diketahui bahwa pengaruh Standar Akuntansi Pemerintah $\left(\mathrm{X}_{1}\right)$ berpengaruh positif dan signifikan terhadap Kualitas Laporan Keuangan Pemerintah Daerah (Y). dari hasil tersebut dapat menjelaskan bahwa dalam penyusunan laporan keuangan itu diperlukannya Standar Akuntansi Pemerintah sesuai dengan Peraturan Pemerintah No.71 tahun 2010 yang menyatakan SAP merupakan persyaratan yang mempunyai kekuatan hukum dalam upaya meningkatkan kualitas laporan keuangan pemerintah di Indonesia. Maka semakin baik Standar Akuntansi Pemerintah yang diterapkan maka akan semakin baik pula kualitas laporan keuangan yang dihasilkan.

Pengaruh Pemanfaatan Sistem Informasi Akuntansi terhadap Kualitas Laporan Keuangan Pemerintah

Berdasarkan hasil analisis bab sebelumnya telah diketahui bahwa Pemanfaatan Sistem Informasi Akuntansi $\left(\mathrm{X}_{2}\right)$ tidak berpengaruh signifikan terhadap Kualitas Laporan Keuangan Pemerintah Daerah (Y). Pemanfaatan SIA dapat meminimalisir terjadi kesalahan dalam pencatatan dan pengelolaan data serta memiliki kontribusi yang kuat terhadap Kualitas LKPD sehingga dapat digunakan sebagai pengambilan keputusan. Namun hal itu saja tidak cukup karena sistem informasi akuntansi juga membutuhkan kontrol oleh para aparat, apabila tidak dikontrol dengan baik maka sistem komputerisasi akan mudah mengalami kendala yang akan menghambat proses pelaporan keuangan yang berkualitas serta dimanfaatkan secara bijak oleh aparat pemerintah.

Pengaruh Pengawasan Keuangan terhadap Kualitas Laporan Keuangan Pemerintah

Berdasarkan hasil analisis bab sebelumnya telah diketahui bahwa variabel Pengawasan Keuangan $\left(X_{3}\right)$ berpengaruh signifikan terhadap Kualitas Laporan Keuangan Pemerintah Daerah (Y). Perlu adanya pengawasan dalam pengelolaan keuangan daerah agar semua proses berjalan secara efisien, efektif sesuai dengan ketentuan peraturan perundang-undangan sehingga bentuk pertanggungjawaban pemerintah mampu meyakinkan bahwa informasi yang disajikan dalam pelaporan keuangan tersebut andal.

\section{KESIMPULAN}

Berdasarkan hasil penelitian yang telah dibahas dapat disimpulkan bahwa secara simultan variabel SAP, SIA dan pengawasan keuangan berpengaruh signifikan terhadap kualitas laporan keuangan pemerintah daerah, standar akuntansi pemerintah berpengaruh positif dan signifikan terhadap kualitas laporan keuangan pemerintah daerah, sistem informasi akuntansi tidak berpengaruh terhadap kualitas laporan keuangan pemerintah daerah dan pengawasan keuangan berpengaruh positif dan signifikan terhadap kualitas LKPD.

\section{SARAN}

Saran yang diberikan secara praktisi manfaat yang diberikan kepada instansi yaitu untuk meningkatkan Kualitas LKPD perlu diperhatikan Penerapan SAP, Pemanfaatan SIA, 
Nanda Saputri Yanti, Pengaruh Penerapan Standar Akuntansi Pemerintah, Pemanfaatan Sistem Informasi Akuntansi Dan Pengawasan Keuangan Terhadap Kualitas Laporan Keuangan Pemerintah

Daerah

dan Pengawasan Keuangan. Suatu standar merupakan pedoman yang telah disusun untuk memperjelas pekerjaan maka setiap pegawai pada bidang akuntansi haruslah dapat memahami SAP agar laporan keuangan yang disusun memiliki kualitas yang baik.

Penggunaan SIA dalam menunjang pekerjaan sangat diperlukan hal ini menuntut kualitas para pegawai agar dapat mengimbangi dan menggunakan teknologi secara tepat. Diharapkan pihak pengelola keuangan daerah khususnya bagian fungsi keuangan/akuntansi agar mampu menjalankan tugas dan fungsinya dengan memanfaatan sebuah sistem seoptimal mungkin, dan menyusun rancangan serta adanya pengendalian Intern

Pengawasan keuangan daerah penting dilakukan dalam lingkup pemerinah agar tidak terjadi kecurangan serta dapat membantu mengontrol kegiatan OPD dalam menggunakan anggaran dan menyusun laporan keuangan. Agar tidak terjadi kemungkinan adanya kesalahan dalam penyusunan LKPD maka fungsi dari pengawasan ini harus dilakukan dengan baik oleh pemerintah daerah maupun pusat.

\section{DAFTAR PUSTAKA}

Andini, Dewi dan Yusrawati. 2015. Pengaruh Kompetensi Sumber Daya Manusia Dan Penerapan Sistem Akuntansi Keuangan Daerah Terhadap Kualitas Laporan Keuangan Daerah Pada Satuan Kerja Perangkat Daerah (Skpd) Kabupaten Empat Lawang Sumatera Selatan. Jurnal Ekonomi, Manajemen dan Akuntansi (Online), 24 (1): (https://journal.uir.ac.id), diakses 16 November 2019.

Azlan, Herwanti, dan Endar. 2015. Pengaruh Kualitas Sumber Daya Manusia, Pemanfaatan Teknologi Informasi, Pengendalian Intern Akuntansi, Dan Pengawasan Keuangan Daerah Terhadap Keandalan Laporan Keuangan Daerah Pada SKPD Pemerintah Kabupaten Lombok Timur" Jurnal Akuntansi Aktual, (Online) 3 (2) 188-198. (journal.um.ac.id), diakses 13 Oktober 2019.

Diani Irma. 2014. Pengaruh Pemahaman Akuntansi, Pemanfaatan Sistem Informasi Akuntansi Keuangan Daerah dan Peran Internal Audit Terhadap Kualitas Laporan Keuangan Pemerintah Daerah. Jurnal Ekonomi Universitas Negeri Padang, (Online) 1-23. (http://ejournal.unp.ac.id) diakses 22 November 2019.

Peraturan Menteri Dalam Negeri Nomor 8 Tahun 2009 Tentang Tata Cara Pengawasan atas Penyelenggaraan Pemerintah Daerah. (Online), (https://m.hukumonline.com), diakses 3 Desember 2019

Sugiyono. 2018. Metode Penelitian Pendidikan Pendekatan Kuantitatif, Kualitatif, dan RED. Bandung: Alfabeta.

Undang-undang Nomor 23 Tahun 2014 Tentang Pemerintah Daerah. (Online), (https://pih.kemlu.go.id), diakses 21 November 2019

Undang-undang Nomor 33 Tahun 2004 Tentang Perimbangan Keuangan Antara Pemerintah Pusat dan Pemerintah Daerah. (Online), (https://luk.staff.ugm.ac.id), diakses 12 Desember 2019

Yuliana, Linna. 2016. Pemahaman Standar Akuntansi Pemerintah, Pengalaman Kerja dan Sistem Informasi Akuntansi Terhadap Kualitas Laporan Keuangan Pemerintah Daerah" Jurnal Publikasi Ilmiah Universitas Muhammadiyah Surakarta. (Online), 1-15 (http://eprints.ums.ac.id) Diakses 19 November 2019. 